\title{
POLA PEMANFAATAN PERIKANAN TANGKAP DI KAWASAN KONSERVASI PERAIRAN KABUPATEN CIAMIS
}

\section{(UTILIZATION PAT'TERNS OF FISHERIES IN MARINE PROTECTED AREA, CIAMIS)}

\author{
Endratno $^{1,2}$, Domu Simbolon ${ }^{2}$, Budy Wiryawan ${ }^{2}$, Roza Yusfiandayani ${ }^{2}$ \\ ${ }^{1}$ Corresponding author \\ ${ }^{2}$ Departemen Pemanfaatan Sumberdaya Perikanan \\ Fakultas Perikanan dan Ilmu Kelautan, Institut Pertanian Bogor \\ E-mail: endratno77@gmail.com
}

\begin{abstract}
Utilization of fishing area in marine protected area in Ciamis waters by various activities may cause multi sectors conflict related to management of the Ciamis waters. The integrated zone system in that area has not been established yet, therefore it is needed to be studied. This paper aimed to analyze resources use of capture fisheries on Marine Protected Area in Ciamis waters. This research used spatial analysis approach for overlaying fishing ground area and other use. The result showed the rules of fishing lines and placement of fishing gear, fishing grounds and the existing zonation. Utilization of fish resources was appropriate in the zone, but fishing gears that still could triger social conflict and its operations did not fit with the sustainable utilization mechanisms. Fishing areas predominantly in coastal areas that need to be developed to encourage the fishermen fishing outside the coastal region.
\end{abstract}

Keywords: Fishing ground, marine protected area, spatial

\begin{abstract}
ABSTRAK
Kegiatan perikanan tangkap berupa area fishing ground pada kawasan konservasi perairan di Kabupaten Ciamis dapat menimbulkan konflik multi sektor dalam pengelolaan perikanan. Integrasi zonasi kawasan konservasi dengan daerah fishing ground belum pernah dilakukan karena batas zonasi kawasan konservasi belum diberikan secara definitif, sehingga perlu dilakukan kajian. Tulisan ini bertujuan untuk menganalisa pola pemanfaatan sumber daya ikan oleh kegiatan perikanan tangkap pada kawasan konservasi perairan Kabupaten Ciamis dengan menggunakan pendekatan analisis spasial. Hasilnya menunjukkan area fishing ground, aturanaturan mengenai jalur penangkapan pada zonasi yang ada pada kawasan konservasi perairan Kabupaten Ciamis secara spasial. Pola pemanfaatan sumber daya ikan telah sesuai pada zona pemanfaatan dan zona perikanan berkelanjutan, namun masih terdapat alat penangkapan ikan yang belum sesuai dengan mekanisme pemanfaatan berkelanjutan. Kegiatan penangkapan ikan dominan berada pada daerah pantai sehingga perlu dikembangkan dengan mendorong nelayan untuk melakukan kegiatan penangkapan ikan di luar wilayah pantai.
\end{abstract}

Kata kunci: Fishing ground, kawasan konservasi perairan, spasial

\section{PENDAHULUAN}

Interaksi pemanfaatan sumber daya alam antara yang satu dengan lainnya akan menimbulkan pergesekan jika tidak ada koordinasi, seperti pemanfaatan perikanan tangkap dengan penerapan kawasan konservasi perairan. Pengelolaan perikanan tangkap identik dengan "produksi dan kesejahteraan masyarakat" sedangkan penerapan kawasan konservasi perairan (KKP) identik dengan "perlindungan sumber daya dan non-profit". Merujuk Peraturan Pemerintah No. 60 tahun 2007 tentang Kon- servasi Sumber Daya Ikan, paling tidak 2 (dua) hal penting dimuat sehingga menjadi paradigma baru dalam konteks pengelolaan kawasan konservasi yaitu pengelolaan diatur dengan sistem zonasi dan kewenangan pengelolaan kawasan konservasi didesentralisasikan kepada pemerintah daerah. Desentralisasi kewenangan pengelolaan kawasan konservasi kepada pemerintah daerah menghapus kekhawatiran akan berkurangnya akses nelayan di kawasan konservasi perairan (Kementrian Kelautan dan Perikanan, 2012). 
Perancangan rencana pengelolaan kelautan perlu memperhitungkan batas spasial dan pola kegiatan perikanan, dan konsistensi daerah yang dijadikan sebagai daerah fishing ground dari tahun ke tahun. Deskripsi distribusi spasial dari tekanan kegiatan penangkapan akan menjadi lebih bermakna pada tingkat lokal jika mencerminkan sensitivitas habitat terhadap tekanan tersebut (Stelzenmüller et al, 2008). Sebagian besar informasi yang diperlukan dalam pengelolaan perikanan dapat diintegrasikan dan dianalisis dalam format spasial. Sistem Informasi Geografis (SIG) merupakan alat yang logis untuk integrasi informasi dan visualisasi skenario manajemen, meningkatkan partisipasi lokal dalam manajemen perikanan berbasis masyarakat. Pengetahuan lokal adalah proses dinamis dan adaptif yang dapat dengan mudah berubah sesuai dengan kebutuhan dan situasi yang berbeda. Lebih lanjut pendekatan ini juga bisa digunakan untuk merumuskan kebijakan perikanan dan perundang-undangan dan manajemen program pada tingkat yang lebih tinggi (De Freitas dan Tagliani, 2009).

Pola pemanfaatan sumber daya ikan, khususnya kegiatan penangkapan ikan pada zonasi kawasan konservasi perlu dibuat secara spasial sehingga dapat menggambarkan interaksi keduanya. Pemanfaatan sumber daya ikan harus sesuai zona peruntukannya dan potensi dampaknya yang dapat ditimbulkan bagi keberlanjutan. Tujuan dari penelitian ini adalah untuk menganalisa pemanfaatan sumber daya ikan oleh aktivitas perikanan tangkap pada kawasan konservasi perairan Kabupaten Ciamis.

\section{METODOLOGI}

\subsection{Metode Pengumpulan Data}

Data primer berupa pemetaan partisipatif (Berkes et al, 2008), yaitu peta fishing ground dan aktivitas penangkapan ikan sesuai dengan alat penangkapan ikan yang dioperasikan. Data sekunder berupa dokumen Perencanaan Zonasi Pengelolaan Wilayah Pesisir dan Pulau-pulau Kecil Kabupaten Ciamis Tahun 2012. Metode yang digunakan adalah metode survei dengan teknik wawancara. Sampel diambil dengan menggunakan metode purposive sampling. Responden nelayan berdasarkan alat tangkap yang digunakan sebanyak $5 \%$ dari jumlah total populasi per alat tangkap.

\subsection{Metode Analisis}

Pola pemanfaatan kawasan dianalisis secara spasial menggunakan Sistem Informasi Geografis (SIG) melalui overlay antara peta zonasi kawasan konservasi yang ada dalam dokumen Perencanaan Zonasi Pengelolaan Wilayah Pesisir dan Pulau-Pulau Kecil Kabupaten Ciamis Tahun 2012 dengan pemetaan partisipatif dari nelayan responden yang ada di kawasan konservasi perairan Kabupaten Ciamis, khususnya terkait daerah penangkapan ikan. Hasil overlay kedua peta tersebut dapat menggambarkan interaksi antara kegiatan perikanan tangkap dengan kawasan konservasi perairan secara spasial seperti lokasi dan luasan area penangkapan ikan (fishing ground) dan potensi konflik yang ada.

\section{HASIL DAN PEMBAHASAN}

Berdasarkan daerah operasi penangkapan dan alat tangkap, perikanan tangkap di Kabupaten Ciamis dapat digolongkan menjadi perikanan skala kecil. Armada penangkapan ikan yang digunakan oleh nelayan Kabupaten Ciamis didominasi perahu motor tempel 1 GT dengan kapasitas mesin 15 PK. Daerah fishing ground nelayan didominasi pada jarak 1-2 mil laut dari garis pantai. McConney dan Charles (2008) menyatakan bahwa nelayan skala kecil beroperasi dekat dengan pantai dan menggunakan penangkap ikan yang relatif kecil. Alat tangkap yang beroperasi di perairan KKP dioperasikan secara one day fishing terdiri dari 6 jenis, yaitu gillnet, pancing rawai, trammel net, bagan, jaring arad dan dogol. Berdasarkan metode pengoperasiannya, jaring arad dan dogol merupakan alat tangkap yang dioperasikan secara aktif, sedangkan bagan tancap dan trammel net dioperasikan secara pasif dan dioperasikan dekat dengan garis pantai, sedangkan gillnet dan pancing rawai tetap dioperasikan secara pasif dan dapat dioperasikan lebih jauh dari garis pantai. 
Daerah penangkapan ikan tersebar merata di seluruh pesisir wilayah Kabupaten Ciamis pada area $<2$ mil laut, sebagian gillnet dan pancing rawai tetap dioperasikan pada area $>2$ mil laut namun tetap dibatasi oleh kedalaman tidak lebih dari 50 meter yang masih dianggap aman untuk pengoperasian alat tangkap (Gambar 1). Dekatnya jarak daerah penangkapan ikan diakibatkan oleh keterbatasan daya jangkau armada yang dimiliki. Estimasi luasan area fishing ground di perairan Kabupaten Ciamis mencapai 9607.58 Ha dengan urutan alat tangkap yang paling luas areanya adalah gillnet, pancing rawai tetap kemudian trammel net. Alat tangkap dengan jumlah yang relatif sedikit juga memiliki luasan fishing ground yang kecil yaitu bagan, jaring arad dan dogol (Tabel 1).
Penempatan alat penangkapan ikan dominan berada pada jalur penangkapan ikan 1A (Gambar 1), yaitu meliputi perairan pantai sampai dengan dua mil laut yang diukur dari permukaan air laut pada surut terendah (Kementrian Kelautan dan Perikanan, 2011), sebagian gillnet dan pancing rawai tetap yang berada pada jalur penangkapan 1B, yaitu meliputi perairan pantai di luar 2 (dua) mil laut sampai dengan 4 (empat) mil laut. Penempatan alat penangkapan ikan belum mengikuti aturan yang sudah ada. Penempatan jalur penangkapan ikan $1 \mathrm{~A}$ sesuai aturan yang ada adalah jaring arad, bagan tancap, gillnet dan trammel net. Sedangkan untuk pancing rawai tetap dan dogol seharusnya ditempatkan pada jalur penangkapan ikan 1B.

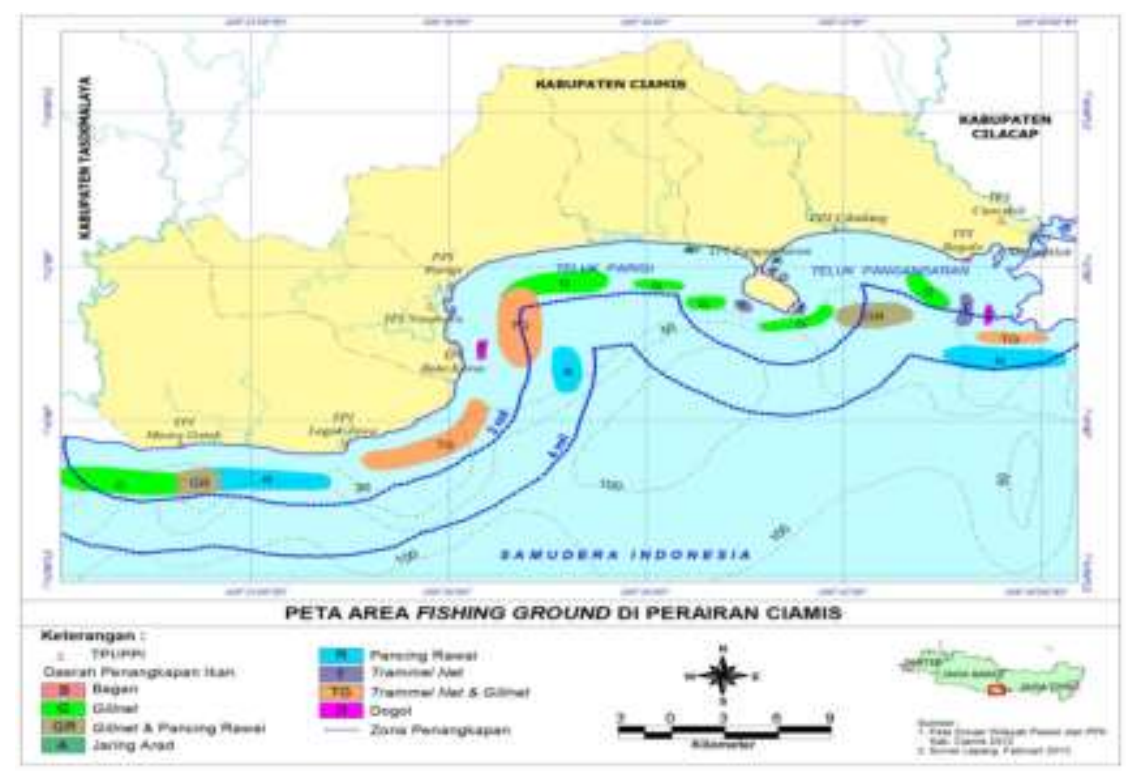

Gambar 1. Area fishing ground

Tabel 1. Estimasi luasan area daerah penangkapan ikan di perairan Kabupaten Ciamis

\begin{tabular}{lc}
\hline Jenis alat tangkap & Luas area fishing ground (Ha) \\
\hline Trammel net \& gillnet & 2786.25 \\
Pancing rawai & 2307.69 \\
Gillnet & 2870.04 \\
Jaring arad & 63.44 \\
Bagan & 11.39 \\
Trammel Net & 326.39 \\
Gillnet \& pancing rawai tetap & 1111.73 \\
Dogol & 130.65 \\
\hline Jumlah total & 9607.58 \\
\hline
\end{tabular}


Wilayah KKP Kabupaten Ciamis telah ditetapkan oleh Surat Keputusan Bupati Ciamis Nomor 15 Tahun 2008 tanggal 28 Februari 2008, namun hingga saat ini perangkat pengelolaan lainnya belum disyahkan dan masih dalam taraf finalisasi. Kawasan konservasi perairan seluas kurang lebih 29.823 Ha meliputi zona inti sebesar $2.36 \%$, zona pemanfaatan A sebesar $8.43 \%$, zona pemanfaatan B sebesar $6.48 \%$ dan zona pemanfaatan $\mathrm{C}$ sebesar $4.55 \%$, sedangkan zona perikanan berkelanjutan sebesar $78.17 \%$. Kawasan konservasi perairan Kabupaten Ciamis terbagi menjadi 3 zona yaitu zona inti, zona pemanfaatan (sub zona A, B, dan C) serta zona perikanan berkelanjutan (Tabel 2). Pada sub zona $\mathrm{C}$ terdapat cagar alam dan taman wisata laut yang dikelola oleh Balai Konservasi Sumberdaya Alam (BKSDA) Kementerian Kehutanan, obyek dan fasilitas wisata dan pemanfaatan perikanan tangkap.

Pembagian zona didasarkan fungsi dengan mempertimbangkan potensi, sumber daya, daya dukung, dan prosesproses ekologis. Zona inti yang berada di dekat muara sungai diperuntukkan sebagai daerah pemijahan dan pembesaran (spawning dan nursery ground) berbagai jenis ikan yang terdiri dari ekosistem mangrove dan terumbu karang sehingga diharapkan dapat berfungsi untuk menjaga kesinambungan keberadaan sumber daya ikan yang ada di zona lainnya. Noor et al (2006) dalam Pranoto (2013) menjelaskan bahwa keberadaan ekosistem mangrove berkaitan erat dengan tingkat produksi perikanan, karena mangrove berperan sebagai (spawning grounds) dan daerah pembesaran (nursery grounds) berbagai jenis ikan, kerang dan spesies lainnya. Lebih lanjut Garcia et al. (2001) dalam Widodo et al (2008) menyatakan bahwa deerah terumbu karang dapat memproduksi 20 - $25 \%$ dari total hasil tangkapan. Zona perikanan berkelanjutan tidak pernah diatur dalam regulasi pengelolaan kawasan konservasi sebelumnya dan dapat dimanfaatkan untuk berbagai aktivitas yang mendukung ekonomi masyarakat sesuai kapasitas lingkungan.

Tabel 2. Pola ruang kawasan konservasi perairan Kabupaten Ciamis

\begin{tabular}{|c|c|c|c|c|}
\hline Fungsi zona & Sub zona & $\begin{array}{c}\text { Luas } \\
\text { (Ha) }\end{array}$ & $\begin{array}{c}\text { Persentase } \\
(\%)\end{array}$ & Lokasi \\
\hline Zona Inti & - & 709 & 2.36 & Kec.Cijulang (Desa Kandangiajar) \\
\hline \multirow[t]{3}{*}{$\begin{array}{l}\text { Zona } \\
\text { Pemanfaatan }\end{array}$} & Sub Zona A & 2531 & 8.43 & $\begin{array}{l}\text { Kec.Cimerak (Desa Kertamukti, } \\
\text { Desa Legokjawa, Desa Masawah) } \\
\text { dan Kec. Cijulang (Desa } \\
\text { Batukaras) }\end{array}$ \\
\hline & Sub Zona B & 1947 & 6.48 & $\begin{array}{l}\text { Kec. Parigi (Desa Karang jaladri, } \\
\text { Desa Ciliang, Desa Cibenda), } \\
\text { Kec. Sidamulih dan Pangandaran } \\
\text { (Desa Wonoharjo, Desa } \\
\text { Pananjung, Desa Pangandaran) }\end{array}$ \\
\hline & Sub Zona C & 1366 & 4.55 & $\begin{array}{l}\text { Kec.Pangandaran (Desa } \\
\text { Pengandaran, Desa Babakan) } \\
\text { dan Kec. Kalipucang (Desa } \\
\text { Putrapinggan, desa Emplak, } \\
\text { Desa Bogolo, Desa Pamotan) }\end{array}$ \\
\hline Zona & & 23471 & 78.17 & Kecamatan pesisir Ciamis \\
\hline Perikanan & & & & (Kec.Kalipucang, Kec. \\
\hline Berkelanjutan & & & & $\begin{array}{l}\text { Pangandaran, Kec. Sidamulih, } \\
\text { Kec. Parigi, Kec. Cijulang dan } \\
\text { Kec. Cimerak }\end{array}$ \\
\hline
\end{tabular}

Sumber: DKP-KC 2012

Pembagian zona menunjukkan bahwa konservasi bukan hanya upaya perlindungan semata, namun juga secara seimbang melestarikan dan meman- 
faatkan keberlanjutan sumber daya yang pada akhirnya tentu saja untuk kesejahteraan masyarakat. Pengaturan sistem zonasi dalam pengelolaan kawasan konservasi merupakan upaya pemenuhan hak-hak bagi masyarakat lokal, khususnya nelayan. Masyarakat diberikan ruang pemanfaatan untuk perikanan di dalam kawasan konservasi (zona perikanan berkelanjutan dan zona pemanfaatan), misalnya untuk budidaya dan penangkapan ramah lingkungan maupun pariwisata bahari dan lain sebagainya.

Efektivitas kawasan konservasi perairan dalam memenuhi fungsi tersebut akan sangat tergantung pada pembatasan yang diterapkan pada kegiatan perikanan dan jenis pemanfaatan lainnya, khususnya ukuran zona inti yang dijadikan perlindungan (no take area) seluas $2.36 \%$ dari luas kawasan (Tabel 2). Luasan zona inti telah sesuai dengan Peraturan Menteri Kelautan dan Perikanan Per.30/Men/2010 tentang Rencana Pengelolaan dan Zonasi Kawasan Konservasi Perairan yang mensyaratkan luasan zona inti yang dimiliki setiap kawasan konservasi perairan paling sedikit $2 \%$ (dua persen) dari luas kawasan.

Hasil overlay antara peta zonasi KKP dan area fishing ground (Gambar 2) menunjukkan tidak terdapat nelayan yang menangkap ikan pada zona inti (no take area) KKP. Sebagian besar alat penangkapan ikan dioperasikan pada zona pemanfaatan dan zona perikanan berkelanjutan. Beberapa jenis alat tangkap seperti trammel net, gillnet dan bagan tancap dioperasikan berdekatan dengan habitat terumbu karang di Cagar Alam Laut (CAL) Pananjung Pangandaran dengan estimasi luasan fishing ground seluas $89.48 \mathrm{Ha}$ (Tabel 3). Trammel net dan gillnet yang dioperasikan secara pasif dapat mengakibatkan tersangkutnya jaring pada terumbu karang. Selain itu, terdapat jaring arad yang dioperasikan berdekatan dengan CAL Pananjung Pangandaran juga dapat mengakibatkan kekeruhan dasar perairan dan berdampak negatif pada ekosistem terumbu karang yang ada. Zonasi kawasan konservasi yang ada belum ditindaklanjuti dengan pemasangan batas definitif dan perlunya zona penyangga setelah zona inti dan di wilayah CAL sehingga dapat meminimalisir kerusa- kan yang ditimbulkan terutama oleh kegiatan penangkapan ikan.

Sebagian fishing ground pancing rawai dan gillnet berada pada zona pertambangan yang berada di luar kawasan konservasi perairan dengan estimasi area fishing ground seluas $1098.6 \mathrm{Ha}$ (Tabel 3). Kawasan konservasi penyu sebagai tempat bertelur dan penangkaran penyu di Kecamatan Legokjawa yang dikelola oleh masyarakat setempat dan Diskanla Kabupaten Ciamis berada dalam zona pertambangan (penambangan pasir), sehingga dikhawatirkan akan berdampak terhadap kelestarian penyu. Pemanfaatan lainnya, seperti eksplorasi pertambangan dapat mengakibatkan dampak langsung terhadap ekosistem karena operasi pertambangan secara mekanis dapat mengganggu dasar perairan dan membunuh organisme secara langsung (FAO, 2003).

Penempatan beberapa alat penangkapan ikan pada kawasan konservasi seharusnya disesuaikan dengan mekanisme pemanfatan berkelanjutan seperti jenis unit penangkapan pada setiap zona penangkapan dan metode pengoperasian alat tangkap (KKP, 2010), terutama yang ditempatkan berdekatan dengan zona inti sebagai nursery ground dan spawning area. Alat tangkap yang dioperasikan adalah alat tangkap yang sifatnya pasif sehingga dapat meminimalisir dampak yang dapat ditimbulkan, seperti pengadukan dasar perairan terutama dekat habitat terumbu karang dan kerusakan terumbu karang akibat tersangkut jaring. Alat tangkap yang mampu mempertahankan keberlanjutan perikanan tangkap adalah alat tangkap yang memenuhi kriteria antara lain, mengunakan teknologi penangkapan ikan ramah lingkungan (Monintja, 2009 dalam Radarwati et al, 2010). Alat tangkap seperti jaring arad, bagan tancap dan jaring dogol bukanlah alat yang sesuai dioperasikan pada zona penangkapan < 2 mil laut (Tabel 4). Bagan tancap dapat mengakibatkan kerusakan karang akibat pondasinya dan dapat menangkap ikan berukuran kecil termasuk juvenil sehingga berdampak pada reduksi populasi terhadap stock ikan dewasa. Jaring dogol dan jaring arad berdasarkan metode pengoperasiannya digolongkan alat tangkap yang bersifat aktif, sehingga tidak sesuai dengan arahan yang ada. 


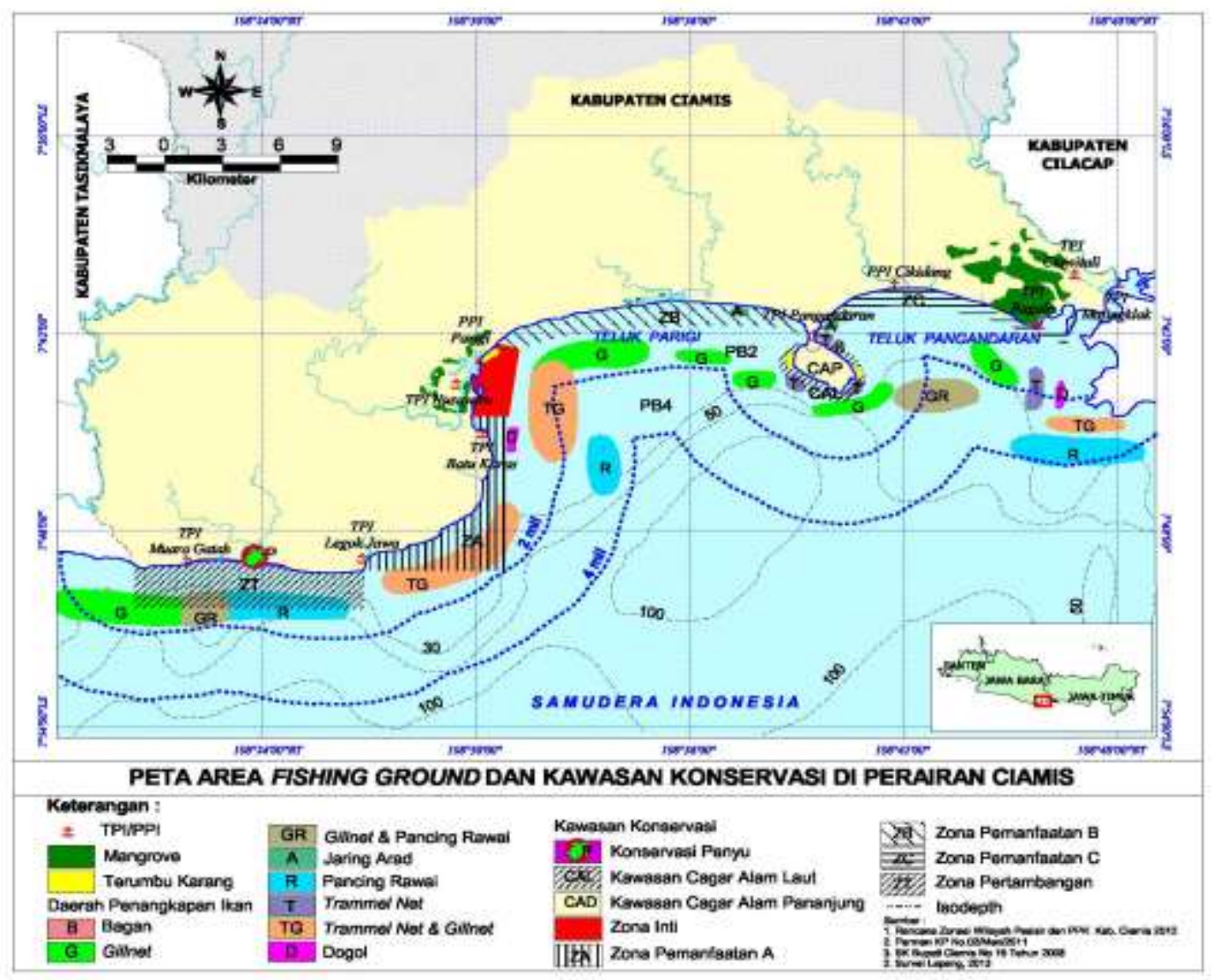

Gambar 2. Lokasi fishing ground pada kawasan konservasi perairan di Ciamis

Tabel 3. Jenis alat tangkap dan estimasi luasan area daerah penangkapan ikan pada zonasi yang ada di perairan Ciamis

\begin{tabular}{llcc}
\hline \multicolumn{1}{c}{ Jenis alat tangkap } & \multicolumn{1}{c}{ Zona } & $\begin{array}{c}\text { Cagar Alam } \\
(\mathrm{CAL})\end{array}$ & $\begin{array}{c}\text { Luas area } \\
(\mathrm{Ha})\end{array}$ \\
\hline Trammel net \& gillnet & Zona Pemanfaatan A & & 687.89 \\
Jaring arad & Zona Pemanfaatan B & & 37.30 \\
Trammel net & & CAL & 73.40 \\
Gillnet & & CAL & 4.69 \\
Bagan tancap & CAL & 11.39 \\
Trammel Net & Zona Pemanfaatan C & & 3.93 \\
Jaring arad & Zona Pemanfaatan C & & 26.14 \\
Pancing rawai & Zona Pertambangan & & 722.13 \\
Gillnet \& pancing rawai & Zona Pertambangan & & 205.87 \\
Gillnet & Zona Pertambangan & & 170.62 \\
Dogol & Zona Pemanfaatan A & & 10.11 \\
\hline Total luasan & \multicolumn{3}{c}{} \\
\hline
\end{tabular}


Tabel 4. Jenis armada penangkapan pada setiap zona penangkapan di perairan Ciamis

\begin{tabular}{|c|c|c|}
\hline Zona & Jenis Armada & Jenis Alat Tangkap \\
\hline $\begin{array}{l}\text { Zona } \\
\text { penangkapan } 2 \\
\text { mil laut }\end{array}$ & $\begin{array}{l}\text { - Perahu tanpa motor } \\
\text { - Perahu motor tempel } \\
\text { bermesin }<25 \mathrm{PK}\end{array}$ & $\begin{array}{l}\text { Alat tangkap yang bersifat pasif: } \\
\text { bubu, jaring insang tetap dengan } \\
\text { panjang ris }<200 \mathrm{~m} \text {, pancing }\end{array}$ \\
\hline $\begin{array}{l}\text { Zona } \\
\text { penangkapan 2-4 } \\
\text { mil laut }\end{array}$ & - Kapal motor < 5 GT & $\begin{array}{l}\text { Alat tangkap pasif dan aktif: jaring } \\
\text { insang dengan panjang tali ris }<200 \\
\mathrm{~m} \text {, pancing rawai dengan jumlah } \\
\text { mata pancing }<100 \text { unit, bagan } \\
\text { perahu dengan jumlah lampu } \\
\text { petromak } 4-6 \text { unit }\end{array}$ \\
\hline $\begin{array}{l}\text { Zona } \\
\text { penangkapan 4-12 } \\
\text { mil laut }\end{array}$ & - Kapal motor 5 - 30 GT & $\begin{array}{l}\text { Alat tangkap pasif dan aktif : payang, } \\
\text { dogol, pukat layang (mini trawl) yang } \\
\text { dilengkapi dengan Juvenile Excluder } \\
\text { Device (JED), gill net, pukat cincin } \\
\text { mini (panjang < } 300 \mathrm{~m} \text { ) }\end{array}$ \\
\hline $\begin{array}{l}\text { Zona } \\
\text { penangkapan di } \\
\text { atas } 12 \text { mil laut }\end{array}$ & - Kapal motor > $30 \mathrm{GT}$ & $\begin{array}{l}\text { Seluruh jenis alat tangkap dengan } \\
\text { teknologi maju namun ramah } \\
\text { lingkungan dengan memperhatikan } \\
\text { penggunaan ukuran mata jaring } \\
\text { (mesh size) : pukat cincin, rawai } \\
\text { dasar, rawai tuna, gillnet besar, stick } \\
\text { held dip net }\end{array}$ \\
\hline
\end{tabular}

Diperlukan tindakan berupa penghapusan beberapa jenis alat penangkapan ikan dan langkah konservasi serta pengelolaan yang sesuai dengan peraturan perundang-undangan, namun harus memperhatikan kebutuhan dan kepentingan masyarakat lokal yang mata pencahariannya dari kegiatan pemanfaatan sumber daya ikan dan biota lainnya di dalam kawasan konservasi. Pengelolaan perikanan yang bertujuan untuk menggabungkan perikanan tangkap dan konservasi dapat dicapai antara lain melalui penggunaan yang tepat dari sejumlah pendekatan, termasuk pengecualian penggunaan alat tangkap yang dioperasikan secara aktif dengan cara ditarik (FAO, 2003).

Dampak lain yang dapat ditimbulkan akibat pengoperasian alat penangkapan ikan pada area fishing ground yang sama (Gambar 2) adalah timbulnya konflik sosial, terutama antara nelayan gillnet dan pancing rawai tetap serta nelayan gillnet dan trammel net akibat tersangkutnya jaring satu sama lain dalam pengoperasiannya. Konflik antar nelayan masih dapat diselesaikan dengan bantuan mediasi rukun nelayan dan pokmaswas yang ada, namun ketika sumber daya ikan semakin terbatas dan unit penangkapan bertambah, maka peluang terjadinya konflik akan semakin tinggi dan koordinasi antar kelompok nelayan mungkin tidak akan efektif lagi. Peningkatan konflik antara kelompok alat tangkap yang berbeda sebagai hasil dari tekanan penangkapan ikan berlebihan merupakan dampak dari interaksi antar alat tangkap (FAO, 2003). Interaksi antar unit penangkapan berdasarkan fishing ground yang sama dan potensi timbulkan konflik dapat dilihat pada Tabel 5.

Pemetaan potensi konflik berdasarkan fishing ground (Tabel 5) dapat menggambarkan interaksi kedua jenis alat tangkap dan potensi konflik ke depan. Kemampuan mengidentifikasi faktor penyebab konflik maka secara simultan akan meningkatkan dukungan terhadap pengelolaan sumber daya perikanan tangkap yang bertanggung jawab (Rusmilyansari et al, 2010). Diperlukan langkah penanganan konflik lebih lanjut, antara lain dengan modernisasi armada maupun alat tangkap sehingga dapat menjangkau fishing ground di luar perairan pantai. 
Tabel 5. Potensi konflik berdasarkan area fishing ground $(F G)$ di perairan Ciamis

\begin{tabular}{|c|c|c|c|c|c|c|}
\hline Alat tangkap & Gillnet & $\begin{array}{l}\text { Pancing } \\
\text { rawai } \\
\text { tetap }\end{array}$ & $\begin{array}{c}\text { Trammel } \\
\text { net }\end{array}$ & Dogol & $\begin{array}{l}\text { Bagan } \\
\text { tancap }\end{array}$ & Jaring Arad \\
\hline Gillnet & & Tinggi & Tinggi & Sedang & Rendah & Rendah \\
\hline $\begin{array}{l}\text { Pancing rawai } \\
\text { tetap }\end{array}$ & Tinggi & & Sedang & Rendah & Rendah & Rendah \\
\hline Trammel net & Ting & Sedang & & Sedang & $\mathrm{Re}$ & Rendah \\
\hline Dogol & Sed & Rendah & Sedang & & Rendah & \\
\hline Bagan tancap & Rendah & Rendah & Ren & $\operatorname{Rer}$ & & Rendah \\
\hline Jaring Arad & Rendah & Rendah & Rendah & Rendah & Rendah & \\
\hline
\end{tabular}

Optimalisasi dan peningkatan atau modernisasi kapal penangkapan ikan dapat dilakukan sebagai salah satu opsi kebijakan. Tidak hanya di daerah pantai saja (0-4 mil laut), tetapi pada wilayah penangkapan 4 mil laut sampai ke arah 12 mil laut lebih (wilayah lepas pantai), sehingga dapat mengurangi tekanan pada sumber daya yang merupakan hasil peningkatan dukungan terhadap kawasan konservasi perairan. Modernisasi kapal perikanan harus dilakukan sebagai bagian dari pengelolaan sumber daya ikan dengan pola operasi penangkapan yang dilakukan secara bertanggung jawab dan berkelanjutan (Mudho, 2011).

Pola pemanfaatan kawasan perikanan tangkap secara spasial diperlukan sebagai bagian dari rencana pengelolaan kawasan konservasi jangka panjang. Rencana pengelolaan perikanan harus melibatkan partisipasi stakeholder dalam proses pengambilan keputusan yang transparan. Zonasi kawasan konservasi harus benar-benar diterapkan, terutama larangan penangkapan ikan di zona inti, sehingga diharapkan pemanfaatan sumber daya ikan dapat dikelola dan dimanfaatkan secara optimal dan berkelanjutan. Pengelolaan yang optimum dari suatu kawasan konservasi dapat dicapai apabila dilakukan penataan batas dalam rangka realisasi legalitas status kawasan konservasi untuk menegaskan batas definitif di lapangan sehingga diperoleh status hukum yang pasti. Dengan demikian, kegiatan perencanaan dan pelaksanaan pengelolaan perikanan pada kawasan konservasi perairan dapat dilakukan secara efektif.

\section{KESIMPULAN DAN SARAN}

\subsection{Kesimpulan}

Pola aktivitas penangkapan ikan lebih banyak dilakukan di wilayah pantai dan telah sesuai pada zona pemanfaatan dan zona perikanan berkelanjutan, namun masih terdapat alat dan teknologi yang belum sesuai dengan mekanisme pemanfaatan berkelanjutan seperti jaring arad, bagan tancap dan jaring dogol serta konflik sosial akibat interaksi alat tangkap.

\subsection{Saran}

1. Perlu dikaji mengenai alat dan teknologi penangkapan ikan yang ramah lingkungan untuk dioperasikan pada kawasan konservasi perairan serta peningkatan/modernisasi armada penangkapan ikan dengan mendorong nelayan untuk melakukan penangkapan ikan di luar wilayah pesisir.

2. Perlu dilakukan penilaian lingkungan dan valuasi ekonomi terhadap rencana zona-zona yang ditetapkan, termasuk zona pertambangan (penambangan pasir) untuk mengetahui dampak yang dihasilkan, khususnya bagi habitat penyu.

\section{DAFTAR PUSTAKA}

Berkes F, Mahon R, McConney P. 2008. Mengelola Perikanan Skala Kecil "Arah dan Metode Alternatif". Lindayati R, Rahman Dako, penerjemah. Ottawa (CA): Inter-national Development Research Centre Canada. 
De Freitas DM, Tagliani PRA. 2009. The use of GIS for the integration of traditional and scientific knowledge in supporting artisanal fisheries management in southern Brazil. Journal of Environmental Management. 90: 2071-2080.

Dinas Kelautan dan Perikanan Kabupaten Ciamis. Laporan Akhir Perencanaan Zonasi Pengelolaan Wilayah Pesisir dan Pulau-pulau Kecil Kabupaten Ciamis 2012. Ciamis (ID).

Ditjen KP3K. 2010. Ketentuan Mengenai Penyusunan Rencana Zonasi Wilayah Pesisir dan Pulau-pulau Kecil (RZWP3K) Kabupaten/Kota. Jakarta (ID): Kementerian Kelautan dan Perikanan.

[FAO] Food Agricultural Organization. 2003. Multiple uses of marine ecosystems. Responsible Fishe-ries in the Marine Ecosystem. Food and Agriculture Organi-zation of the United Nations and CABI Publishing, Cambridge, MA, 2003. 448 pages.

KKP 2012. Kawasan Konservasi untuk Mendukung Ekonomi Biru, Kamis, 05 Juli 2012; [diunduh 2013 Mei 3]. Tersedia pada: http// http:// kkji.kp3k.kkp.go.id.

McConney dan Charles. 2008. Managing Small-Scale Fisheries, Moving toward People-Centered Persprectives. Handbook of Marine Fisheries Conservation and Mana-gement. 12 hal. http://husky1. smarys.ca/ charles/PDFS_2005/059.pdf.

Mudho Y. 2011. Modernisasi Armada Perikanan. Jakarta (ID): Cakra Books.

Pranoto S. 2013. Pengelolaan ekosistem mangrove yang berkelanjutan di muara Sungai Wulan Demak. Jurnal Mitra Bahari. Volume 7 No.1.

Pemerintah Republik Indonesia. 2011. PerMen KP No.02/Men/2011 tentang Jalur Penangkapan Ikan dan Penempatan Alat Penangkapan Ikan dan Alat Bantu Penangkapan Ikan di Wilayah Pengelolaan Perikanan Negara Republik Indonesia. Departemen Kelautan dan Perikanan. Jakarta (ID).
Pemerintah Republik Indonesia. 2010. PerMen KP No. 30/Men/2010 tentang Rencana Pengelolaan dan Zonasi Kawasan Konservasi Perairan. Departemen Kelautan dan Perikanan. Jakarta (ID).

Pemerintah Republik Indonesia. 2007. PP No. 60 Tahun 2007 tentang Konservasi Sumber Daya Ikan. Lembaran Negara RI Tahun 2007. Sekretariat Negara. Jakarta (ID).

Radarwati S, Baskoro M, Moninjta D. R, Purbayanto A. 2010. Alokasi optimum dan wilayah pengembangan perikanan berbasis alat tangkap potensial di Teluk Jakarta. JTMPL. 1 (2) : 189-198.

Rusmilyansari, Wiryawan B, Haluan J, Simbolon D. 2010. Model pengelolaan sumber daya perikanan tangkap berbasis resolusi konflik. JTMPL. 1 (2) : 177-188.

Stelzenmüller V, Stuart I. Rogers, Craig M. Mills. 2008. Spatio-temporal patterns of fishing pressure on UK marine landscapes, and their implications for spatial planning and management. ICES Journal Marine Science. 65 (6): 10811091.

Widodo J, Suadi. 2008. Pengelolaan Sumberdaya Perikanan Laut. Yogyakarta (ID): Gajah Mada University $\operatorname{Pr}$. 